\title{
THE ANALYSIS AND SYNTHESIS OF STRATEGIC MANAGEMENT RESEARCH IN THE THIRD SECTOR FROM EARLY 2000 THROUGH TO MID-2009
}

\author{
Jarosław DOMAŃSKI \\ Faculty of Management \\ Warsaw University of Technology, Warsaw, Poland \\ email: j.domanski@wz.pw.edu.pl
}

\begin{abstract}
The purpose of this paper is to analyse the contemporary literature on strategic management in non-profit organizations. The area at hand is divided into five categories: modern management and strategic management approaches/theories; analysis of the roles of externalities and internalities in the Third Sector; review of how strategic management has been applied for non-profit organizations; review of applications and enhanced identification of one or more strategies utilised by non-profit organizations; application of specific methods and tools in strategic management. Four dilemmas faced by modern management theory serve as a synthetic axis. First, how can the existing commercial management concepts and techniques be best adapted to the realities of the non-profit sector? Secondly, which of the established schools of strategic management is the most relevant one for non-profits? In fact, is it appropriate to look for a brand new school of thought? Thirdly, and this is again related to academic pursuits, what coherent theory can explain the efficiency of non-profit organizations. Fourthly, there is the dilemma what strategy to employ when faced with a choice between the willingness and the need to apply competitive strategies and the co-operative strategy in the third sector.
\end{abstract}

Key words: strategic management, non-profit organizations, Third Sector, strategy, strategic planning, competitiveness.

\section{Introduction}

There are two underlying observations for this paper. First, strategic management is critically important for the growing Third Sector and not for managers alone but also for researchers who study management and develop new theories. The other observation is that there is a visible lack of literature attempting to characterise and recapitulate existing theories and research findings in the area of strategic management in the nonprofit sector developed since early 2000.

The Third Sector has for many years now been considered the fastest growing socio-economic activity segment in modern democracies (Salamon and Anheier [53, 54], Lauer [36], Sargeant [55]). The size of the sector and social significance of non-profit organizations necessitate inclusion of non-profit issues in management theory. Peter Drucker states that forty years ago, 'management' was a very bad word in non-profit organizations. It meant 'business' to them, and the one thing they were not was a business (Drucker [21]). However, specialised knowledge of management is increasingly critical today. There have been some attempts to develop new or adapt existing management concepts, methods and tools to make them relevant for the Third Sector. In all its dimensions, strategic man- agement can be a useful tool in running a non-profit organization (Bryson [8, 9], Kemp and Kemp [34], Mulhare [42], Courtney [17], Goold [25]). These authors stress that it will lead to the amplification of their strengths and help them grasp environmental opportunities. Most of all, however, it is a remedy for most weaknesses and challenges faced by the organizations nearly on a daily basis. Further, it can be instrumental in mounting an adequate and effective response to major threats from the environment. Non-profit organizations may then be more credible for their stakeholders which should directly strengthen their financial and human resource base.

A review of management literature and studies of non-profit organizations reveal a certain pattern: the sector is lagging behind the business sector by some 15 years in terms of management theory and practice. Literature on enterprise strategic planning emerged in the 1960s and a similar literature on the non-profit sector was first published in mid-1970s. As underlined by Roger Courtney, researches were looking for ways to adapt for the sector the following methods and techniques derived from strategic management: SWOT analysis, PEST, Ansoff's matrix, Porter's sectoral analysis (5 Porterian forces), Boston Consulting Group matrix analysis, stakeholder analysis (Courtney [17]). 
Desk research regarding the use of strategic management concepts in the Third Sector was carried out by Melissa Stone and her team and she came up with a number of conclusions with regard to the then state of our knowledge (Stone, Bigelow and Crittenden [61]). She reviewed 66 papers published in major business and non-profit magazines between 1977 and 1992. Her work was pivotal for later authors on the subject who used it as a solid reference material reflecting the state of knowledge in the period.

Our paper is an attempt at filling the time gap in the literature on strategic management in the Third Sector. Whereas much could have changed in management theory since Melissa Stone's work it is pertinent to review the current research focus and the proposed theories in the early $21^{\text {st }}$ century. Equally, it is important to identify at least some of the dilemmas faced by management theoreticians.

This paper has identified 50 magazine articles on strategic management and more specifically on strategic planning between 2000 and July 2009. The first section describes the desk research methodology applied here.

The findings section provides a brief description of each paper and assigns it to a specified research methodology. The paper discusses more than empirical research and this approach may be useful for future authors looking for texts offering a different characteristic. For example, if they show interest in survey studies they will choose an article focusing on surveys; otherwise, they will look for a more conceptually oriented text based primarily on the intuitive method.

Section Three provides a brief summary of conclusions each of the authors offered in his/her paper. Notably, innovative conclusions were highlighted as much as possible to avoid redundancy. All the conclusions are categorised in five key areas, i.e. current management and strategic management approaches/theories; analysis of the roles of externalities and internalities in the Third Sector; review of how strategic management has been applied for non-profit organizations; review of applications and enhanced identification of one or more strategies utilised by non-profit organizations; application of specific methods and tools in strategic management. Again, this format facilitates structured use of the analysis by researchers and practitioners.

The synthetic section is designed to project new trends in management theory and new fields of research into the strategic management in the Third Sector.
As a result, four major dilemmas faced by contemporary management theory have been distilled.

\section{$2 \quad$ Method}

The study used EBSCOhost, an online scientific database. The key words used during the search were nonprofit and strategic management and dates: since 2000 (i.e. one year after the publication of the work by Melissa Stone et al., as quoted above) till the most recent publications in 2009. The search generated 83 items. With unscientific texts, book reviews etc. left out the number was reduced to 29 (see Table 1, lines 1 - 29, for a brief description).

Subsequently, the search was repeated with modified key words: strategic planning (instead of strategic management). The number of results returned was 231 and a selection is presented in Table 1 in lines $30-48$. In this selection, entries previously acknowledged were rejected. Uniqueness and significance of findings and conclusions were the factors which ultimately help produce the final list. In addition, the sample included texts marked as online first or early view, which are approved papers in electronic form awaiting print. This part of the study covered the following periodicals: Nonprofit and Voluntary Sector Quarterly, Voluntas: International Journal of Voluntary \& Nonprofit Organizations, International Journal of Nonprofit \& Voluntary Sector Marketing - these published texts on strategic management in non-profit organizations the most often or provided on-line access to approved, yet unprinted papers. Hence, the sample was extended by two more entries (marked 49 and 50). In total, more than 300 indexed online databases entries were analysed.

The term 'intuitive method' used above is to be understood as a purely intellectual pursuit which consists in a consideration of concepts, presumption, issues, projects and other elements of the broadly defined research work. The 'survey method' is one which asks questions and generates answers and is employed where the researcher wants to receive statements from the sampled population for further analysis. The concept of 'critical analysis' is a desk research which analyses and critiques the literature on a subject. The 'monographic method' will lead to a comprehensive description and a detailed analysis of a single unit or a small number of characteristic units in a sampled population (Pieter [45]). 
If the description uses several cases to exemplify a point the terms 'case study' is used. Each of the analysed paper did clearly rely on desk research so this was underlined only in cases where this was the only method used or was equally important as other methods which have been identified.

\section{Results}

In Table 1, column (2) presents the name(s) of authors and the year of publication of the analysed paper; column (3) summarises the subject of the study and column (4) identifies the research method employed.

\section{$4 \quad$ Analysis}

The analysis of the material yields a series of general conclusions. While researchers appear to take much interest in strategic management in the Third Sector the sheer number of empirical studies is somewhat lower than at the end of the $20^{\text {th }}$ century. A review completed by Melissa Stone at al. which covered the period between 1977 and 1992 or 15 years revealed 66 empirical (surveys and case studies) studies in the area, which averages at 4,4 publications per year (Stone, Bigelow and Crittenden [61]). From 2000 through to mid-2009, i.e. during 9,5 years there were 50 studies, including 21 based on surveys, 5 case study reports, 17 intuitive and 2 critical analyses. Thus, according to the Stone's classification there were 2,7 studies per year.

Researchers have apparently focused on five different aspects of the subject: current management and strategic management approaches/theories; analysis of the roles of externalities and internalities in the Third Sector; review of how strategic management has been applied for non-profit organizations; review of applications and enhanced identification of one or more strategies utilised by non-profit organizations; application of specific methods and tools in strategic management.

The first group of papers address current management and strategic management approaches/theories such as complexity science (Paarlberg and Bielefeld [43]), knowledge management (Renshaw and Krishnaswamy [49]), intellectual capital (Kong [35]), key competences
(Bryson, Ackermann and Eden [10]), value management (Moore [41]), open systems theory (Starnes [60]). Clearly, most authors subscribe to the resource-based view of strategic management.

Laurie Paarlberg emphasises that current theories of strategic management, mainly top-down in structure, are not relevant to non-profit organizations which inherently rely on the participation and guidance of various stakeholder groups. She claims that complexity science can be a helpful tool while explaining the strategic management processes, content and implementation (Paarlberg and Bielefeld [43]). It is stressed that the concept of intellectual capital is more effective in the context of non-profit organizations than other contemporary theories of strategic management (Kong [35]).

Sharon Renshaw also notices that non-profits exposed to a competitive market place need a compatible strategic management approach, which includes the need to manage their knowledge resources (Renshaw and Krishnaswamy [49]).

The commercial strategy model applied in non-profit organizations is hinged upon the market, competition and clients/customers, and as such it is not adequate for the Third Sector. Here, the strategy should address the social value generation, sources of relevance and support and operational capacity to deliver value (Moore [41]).

John Bryson stresses the role of managing key competences. He believes that efficient management of key competences in an organization will imply improved performance, stronger relationships with peer organizations due to the same or similar shared values, and better capacity to formulate strategic plans. Further, he observes that the 'livelihood scheme' of generating a business model based on key competences may be successfully applied in non-commercial organizations (Bryson, Ackermann and Eden [10]).

Non-profit organization should be managed as openended systems and form strategic alliances as a means to pursue their missions (Starnes [60]).

The resource-based view of strategic management is also close to the hearts of authors who analyse the role of external and internal factors in the Third Sector. 
Table 1. Review of Modern Literature on Strategic Management in Non-Profit Organizations (source: own work)

\begin{tabular}{|c|c|c|c|}
\hline & Author, year of publication & Subject & Study method \\
\hline (1) & (2) & (3) & (4) \\
\hline 1 & $\begin{array}{l}\text { Paarlberg and Bielefeld, } \\
2009[43]\end{array}$ & $\begin{array}{l}\text { Foundations, parameters and impact of complexity science } \\
\text { on strategies of public good organizations }\end{array}$ & intuitive \\
\hline 2 & Gunby Jr, 2009 [27] & $\begin{array}{l}\text { Study of impact of one of the strategic management models } \\
\text { on organizations' performance, including non-profit } \\
\text { organizations }\end{array}$ & survey \\
\hline 3 & $\begin{array}{l}\text { LeRoux and Goerdel, } \\
2009 \text { [37] }\end{array}$ & $\begin{array}{l}\text { Study of an empirical model where various organizational } \\
\text { factors influence the organization's activity. Explanation } \\
\text { of one of the aspects of strategic management }\end{array}$ & survey \\
\hline 4 & $\begin{array}{l}\text { Renshaw and Krishnaswa- } \\
\text { my, 2009 [49] }\end{array}$ & $\begin{array}{l}\text { Emphasised need for strategic knowledge management } \\
\text { in non-profit organizations }\end{array}$ & $\begin{array}{l}\text { intuitive, } \\
\text { critical analysis }\end{array}$ \\
\hline 5 & $\begin{array}{l}\text { Cochran, David and Gibson, } \\
2008 \text { [16] }\end{array}$ & Mode of creating an effective mission statement & $\begin{array}{l}\text { intuitive, } \\
\text { critical analysis }\end{array}$ \\
\hline 6 & Jarmon, $2008[31]$ & Competition between non-profit and for-profit organizations & critical analysis \\
\hline 7 & Speckbacher, 2008 [58] & $\begin{array}{l}\text { Considerations on the role of stakeholders in the context } \\
\text { of economics and governance theory in organizations }\end{array}$ & $\begin{array}{l}\text { intuitive, } \\
\text { critical analysis }\end{array}$ \\
\hline 8 & Schalm, 2008 [56] & $\begin{array}{l}\text { Application of the strategic score card in non-profit } \\
\text { organizations (long-term medical care) in Canada }\end{array}$ & $\begin{array}{l}\text { intuitive, } \\
\text { critical analysis, } \\
10 \text { interviews }\end{array}$ \\
\hline 9 & $\begin{array}{l}\text { Carman and Fredericks, } \\
2008[11]\end{array}$ & $\begin{array}{l}\text { The role of evaluation as a tool, } \\
\text { inter alia in strategic management }\end{array}$ & survey \\
\hline 10 & Kong, 2007 [35] & $\begin{array}{l}\text { The meaning of the intellectual capital concept } \\
\text { in strategic management of non-profit organizations }\end{array}$ & $\begin{array}{l}\text { intuitive, } \\
\text { critical analysis }\end{array}$ \\
\hline 11 & $\begin{array}{l}\text { Bryson, Ackermann and } \\
\text { Eden, } 2007[10]\end{array}$ & $\begin{array}{l}\text { The role of key competences according } \\
\text { to the resource-based view of strategic management }\end{array}$ & $\begin{array}{l}\text { intuitive, } \\
\text { critical analysis }\end{array}$ \\
\hline 12 & $\begin{array}{l}\text { Vandijck, Desmidt and } \\
\text { Buelens, } 2007 \text { [63] }\end{array}$ & Mission statement in Flemish non-profit organizations & survey \\
\hline 13 & $\begin{array}{l}\text { Taylor and McGraw, } \\
2006[62]\end{array}$ & $\begin{array}{l}\text { Human resources management as a strategy in strategic } \\
\text { management in sports organizations in Australia }\end{array}$ & survey \\
\hline 14 & $\begin{array}{l}\text { Golensky and Mulder, } \\
2006[24])\end{array}$ & $\begin{array}{l}\text { Study of strategies employed in } 112 \text { organizations } \\
\text { in California }\end{array}$ & survey \\
\hline 15 & Chew, 2006 [13] & $\begin{array}{l}\text { Positioning strategy in strategic management, } \\
\text { study of organizations in the United Kingdom }\end{array}$ & survey \\
\hline 16 & $\begin{array}{l}\text { Hafsi and Thomas, } \\
2005[28]\end{array}$ & $\begin{array}{l}\text { Effect of volatile environment on strategic management } \\
\text { in philanthropic organizations in Montreal }\end{array}$ & monography \\
\hline 17 & $\begin{array}{l}\text { Chien-Tzu Tsai et al., } \\
2005[15]\end{array}$ & $\begin{array}{l}\text { An innovative strategy case study in Industrial Technology } \\
\text { and Research Institute, Taiwan }\end{array}$ & case study \\
\hline 18 & Alfirević et al., 2005 [1] & $\begin{array}{l}\text { Application of the strategic score card, } \\
\text { a case study from Croatia }\end{array}$ & case study \\
\hline 19 & Reeves and Ford, 2004 [48] & $\begin{array}{l}\text { Differences in strategic management between non-profit } \\
\text { and for-profit organizations }\end{array}$ & survey \\
\hline 20 & Pijl and Sminia, 2004 [46] & $\begin{array}{l}\text { Relevance of strategic management } \\
\text { for non-profit organizations - case study }\end{array}$ & case study \\
\hline 21 & Carney, 2004 [12] & $\begin{array}{l}\text { The role of middle management in strategic management } \\
\text { in hospitals }\end{array}$ & survey \\
\hline 22 & Fillis, 2003 [22] & $\begin{array}{l}\text { Image, reputation and identity as issues in strategic } \\
\text { management }\end{array}$ & intuitive \\
\hline 23 & $\begin{array}{l}\text { Katsioloudes and Tymon, } \\
2003[33]\end{array}$ & $\begin{array}{l}\text { Study of the use of strategic management in a sample } \\
\text { of } 53 \text { organizations in Philadelphia }\end{array}$ & survey \\
\hline 24 & Reussner, 2003 [50] & Strategic management model for museums & $\begin{array}{l}\text { intuitive, } \\
\text { critical analysis }\end{array}$ \\
\hline 25 & Speckbacher, 2003 [59] & $\begin{array}{l}\text { Efficiency management in non-profit organizations, } \\
\text { role of the strategic score card }\end{array}$ & critical analysis \\
\hline 26 & $\begin{array}{l}\text { Frumkin and Casey, } \\
2003[23]\end{array}$ & Components of strategic management for schools & $\begin{array}{l}\text { intuitive, } \\
\text { critical analysis }\end{array}$ \\
\hline
\end{tabular}




\begin{tabular}{|c|c|c|c|}
\hline 27 & Berrett and Slack, $2001[5]$ & Sponsor acquisition strategy in sports organizations & survey \\
\hline 28 & Inamdar et al., $2000[30]$ & Application of the strategic score card in health care & monography \\
\hline 29 & Crittenden, 2000 [18] & $\begin{array}{l}\text { Study of } 31 \text { organizations regarding strategic management } \\
\text { impact on financial strategies }\end{array}$ & survey \\
\hline 30 & $\begin{array}{l}\text { Hwang and Powell, } \\
2009 \text { [29] }\end{array}$ & $\begin{array}{l}\text { Strategic planning as an indicator of rational operations } \\
\text { in organizations with hired paid personnel and full-time } \\
\text { managers in the San Francisco area. Rational activity } \\
\text { is on a higher level in such organizations }\end{array}$ & survey \\
\hline 31 & Bratt, 2009 [6] & $\begin{array}{l}\text { The role of strategic planning in more efficient operations } \\
\text { in a volatile market. It can help organizations which focus } \\
\text { on housing for the poor }\end{array}$ & $\begin{array}{l}\text { intuitive, } \\
\text { critical analysis }\end{array}$ \\
\hline 32 & $\begin{array}{l}\text { Chew and Osborne, } \\
2009[14]\end{array}$ & $\begin{array}{l}\text { Identification of key factors influencing the positioning } \\
\text { strategy in organizations. The factors make up a theoretical } \\
\text { model which is better aligned with charities }\end{array}$ & $\begin{array}{l}\text { intuitive, survey, } \\
\text { critical analysis }\end{array}$ \\
\hline 33 & $\begin{array}{l}\text { Mazzarol and Soutar, } \\
2008 \text { [39] }\end{array}$ & $\begin{array}{l}\text { Study of Australian education institutions with regard } \\
\text { to Porterian positioning strategies. Findings demonstrate } \\
\text { that organizations which fail to use consistent strategies } \\
\text { note less satisfactory performance }\end{array}$ & survey \\
\hline 34 & $\begin{array}{l}\text { Johnson and Lipp, } \\
2007 \text { [32] }\end{array}$ & $\begin{array}{l}\text { A case of a cognitive map employed for goal identification, } \\
\text { a the first step in strategic planning for a major university } \\
\text { faculty }\end{array}$ & monography \\
\hline 35 & $\begin{array}{l}\text { Slyke van and Brooks, } \\
2005[57]\end{array}$ & $\begin{array}{l}\text { Study and model for a better alignment of the fund-raising } \\
\text { strategy to socio-demographic and economic characteristics } \\
\text { of individual donors }\end{array}$ & $\begin{array}{l}\text { intuitive, } \\
\text { survey }\end{array}$ \\
\hline 36 & $\begin{array}{l}\text { Rhodes and Keogan, } \\
2005 \text { [51] }\end{array}$ & $\begin{array}{l}\text { Analysis of individual strategic choices and strategic plan- } \\
\text { ning process in non-profit organizations in Ireland, sample } \\
\text { of } 25 \text { organizations }\end{array}$ & survey \\
\hline 37 & $\begin{array}{l}\text { Balser and McClusky, } \\
2005[2]\end{array}$ & Stakeholder relations management, two case studies & case study \\
\hline 38 & $\begin{array}{l}\text { Pike, Roos and Marr, } \\
2005 \text { [47] }\end{array}$ & $\begin{array}{l}\text { The role of intangible assets in value creation and strategic } \\
\text { planning }\end{array}$ & case study \\
\hline 39 & $\begin{array}{l}\text { Brown and Iverson, } \\
2004 \text { [7] }\end{array}$ & $\begin{array}{l}\text { Study of } 132 \text { organization regarding strategy conceptualisa- } \\
\text { tion vis-à-vis products, services and organizational struc- } \\
\text { tures; } 4 \text { types of strategic behaviours have been identified }\end{array}$ & survey \\
\hline 40 & Griggs, 2003 [26] & $\begin{array}{l}\text { Effect of strategic planning on organization's performance. } \\
\text { Study of } 148 \text { organizations in Australia }\end{array}$ & survey \\
\hline 41 & Miller, 2002 [40] & $\begin{array}{l}\text { Issues of strategic management in religious organizations; } \\
\text { sources of competitive advantages, role of strategy and } \\
\text { strategic alliances }\end{array}$ & $\begin{array}{l}\text { intuitive, } \\
\text { critical analysis }\end{array}$ \\
\hline 42 & Barman, 2002 [13] & $\begin{array}{l}\text { Differentiation strategy in the context of the changing } \\
\text { environment and competitiveness of non-profit organiza- } \\
\text { tions }\end{array}$ & monography \\
\hline 43 & $\begin{array}{l}\text { Pavičić, Renko and Al- } \\
\text { firević, 2001 [44] }\end{array}$ & $\begin{array}{l}\text { Role of competition and competitiveness analysis in non- } \\
\text { profit organizations }\end{array}$ & survey \\
\hline 44 & Mara, 2000 [38] & $\begin{array}{l}\text { Use of computer tool to support strategic planning in small } \\
\text { non-profit organizations }\end{array}$ & monography \\
\hline 45 & $\begin{array}{l}\text { Crittenden and Crittenden, } \\
2000[19]\end{array}$ & $\begin{array}{l}\text { Study of characteristics of non-profit organizations and their } \\
\text { impact on strategic planning }\end{array}$ & survey \\
\hline 46 & Moore, 2000 [41] & $\begin{array}{l}\text { Value management as organizational strategy, among others } \\
\text { in non-profit organizations }\end{array}$ & intuitive \\
\hline 47 & Bart and Tabone, 2000 [4] & $\begin{array}{l}\text { Study of the relationship between mission statement and } \\
\text { performance of Canadian hospitals }\end{array}$ & survey \\
\hline 48 & Starnes, 2000 [60] & $\begin{array}{l}\text { Impact of open systems theories and strategic alliances } \\
\text { on competitive advantage in non-profit organizations }\end{array}$ & $\begin{array}{l}\text { intuitive, } \\
\text { critical analysis }\end{array}$ \\
\hline 49 & Domański, 2009 [20] & $\begin{array}{l}\text { Analysis of strategic groups of } 485 \text { Polish organizations } \\
\text { focusing on education and culture. Identification and de- } \\
\text { scription of } 5 \text { groups, use of cluster analysis }\end{array}$ & survey \\
\hline 50 & $\begin{array}{l}\text { Ridder and McCandless, } \\
2008 \text { [52] }\end{array}$ & $\begin{array}{l}\text { Critical role of human resources management and its } \\
\text { uniqueness in non-profit organizations }\end{array}$ & $\begin{array}{l}\text { intuitive, } \\
\text { critical analysis }\end{array}$ \\
\hline
\end{tabular}


They recognise the role of: the environment (Hafsi and Thomas [28]), human resources (Taylor and McGraw [62] and Ridder and McCandless [52]), middle management (Carney [12]), intangible resources (Pike, Roos and Marr [47]), stakeholders (Speckbacher [58]) and (Balser and McClusky [2]).

Taïeb Hafsi mentions the stimulating role of a volatile environment. Strategies in philanthropic organizations are more effective and ensure viability and growth is they are not hinged upon the concept of autonomy and take environmental dependence for granted and acknowledge it affects the organization's behaviours (Hafsi and Thomas [28]).

Efficient human resources management can make a difference for non-profit organizations. However, its basis components known from the private sector should tuned to the needs of the Third Sector which works with volunteers along with paid staff. Very few non-profit organizations have a human resources management strategy; (Taylor and McGraw [62], Ridder and McCandless [52]). In this context, it is essential that the strategy be formulated jointly by the leadership and personnel alike and this includes middle management. This translates into improved ownership and more effective implementation (Carney [12]).

Further, it is acknowledged that intangible assets of a non-profit organization play an essential role in value creation (Pike, Roos and Marr [47]).

Stakeholders are looked upon as key resources of the Third Sector. The key challenge of non-profit organizations is to increase the value of the contributions made by stakeholders and yet to minimise transaction costs and the cost of decision-making (Speckbacher [58]). Organizations which build their external relations with stakeholders by projecting an image of a well managed organization and do it consistently with various stakeholder groups tend to receive accolade from external evaluators (Balser and McClusky [2]).

The third group of papers relates to the application of strategic management for non-profit organizations. Normally, research papers aim at demonstrating the relevance of this concept for the Third Sector, analysing the scope of implementation, building partial models either for specific types of organization (museums, schools, sports or religious organizations) of for specific strategic planning phase (mission, vision, planning).

\section{$5 \quad$ Strategic Planning}

Strategic planning in non-profit organizations is positively correlated with their performance in the following dimensions: orientation to external environment, functional orientation and focus on key personnel involvement (Griggs [26]). Strategic planning helps organizations better concentration on the rapid changes in the environment (Bratt [6]).

Non-profit organizations are committed to strategic planning yet managers appear to see an inadequate contribution of analyses conducted in the process (Katsioloudes and Tymon [33]). The relative importance attached by organizations to detailed planning is closely correlated with their nature and pressure on traditional organization structures - organizations which have a management board, paid administration, voluntary members and various committees engage their stakeholders (e.g. administration, volunteers and clients) in the planning process (Crittenden and Crittenden [19]).

Organizations which have existed for a long time attach greater importance to strategic planning but they have no influence over this process: the age of members, fund-raising sources, education of administration staff and the level of bureaucracy (Crittenden and Crittenden [19]). Organizations must take into account the qualitative dimension of the strategic management process while evaluating it; a multi-dimensional approach to this process ensures a greater return on assets (ROA) (Gunby Jr [27]).

\section{$6 \quad$ Strategies}

Organizations employ a wide variety of both internal and external strategies most of which meet or even exceed their expectations and the selection of the strategy should depend on its effectiveness and efficiency (Golensky and Mulder [24]). Strategies developed by organizations place special emphasis on such dimensions as structure and mission (Rhodes and Keogan [51]).

A number of observations regarding their strategies imply a view that non-profit organizations (churches) are competitive organizations. Strategies must on occasion result from the choice between tradition and innovation and may be guided by collaboration (Miller [40]). Organizations should find an adequate response to the two fundamental strategic dilemmas: the choice 
between membership and influence, and between representation and control (Pijl and Sminia [46]). Organizations are successful when: the various strategies that they employ are closely interrelated and oriented towards funding from diverse sources, they apply marketing tools and their growth comes from improved utility of their offer (Crittenden [18]).

\section{$7 \quad$ Mission Statement}

Managers in non-profit organizations realise that a well stated mission may be extremely advantages (Vandijck, Desmidt and Buelens [63]). An effective process of developing a mission statement may involve the following steps: introduction, analysis of: components, communication, connotations, and applicability (Cochran, David and Gibson [16]). According to research, top management makes the biggest contribution towards formulating a mission statement (Bart and Tabone [4]).

The involvement of a broad spectrum of stakeholders in developing a mission statement is positively correlated with performance and the process should not be top down but informal and creative across a possibly broad range of participating stakeholders (Bart and Tabone [4]). However, non-governmental organizations' leaders should not only concentrate on fulfilling the mission but also pay attention to managing their organizations through a fast changing environment (Frumkin and Casey [23]).

\section{$8 \quad$ Key Sources of Effectiveness}

Factors affecting the performance and effectiveness of non-profit organizations are addressed in literature. It is recognised that organizations management by fulltime managers and employing paid staff have more rationalised operations (Hwang and Powell [29]).

Factors which have a major impact on organizations' performance are: experience accumulated in the course of collaborative efforts, adequate relations with major donors, managers equipped with lobbying skills, dependence on government resources and competition for resources in the environment (LeRoux and Goerdel [37]).

\section{Other}

A partial strategic management model for museums oriented towards granting visitor access to resources has been developed by Eva Reussner. She claims that a strategic management model for a non-profit organizations should be comprehensive and attuned to externalities such a government (culture) policy and the obligations arising from public functions (Reussner [50]).

The role of reputation, image and identity is emphasised by Ian Fillis. Reputation, identity and image management may be relevant also in small organizations and may be viewed through the lens of marketing and enterprise (Fillis [22]).

While there are significant differences in strategic management and performance evaluation between nonprofit and for-profit organization it is plausible to study them at the same time (Reeves and Ford [48]).

The analyses of applications and a better definition of one or more specific strategies employed by nonprofit organizations fall under fourth identified category of papers. Authors focus on: competitive strategies (Jarmon [31], Pavičić, Renko and Alfirević [44]); positioning strategies (Chew [13], Chew and Osborne [14], Mazzarol and Soutar [39]) innovation strategies (Chien-Tzu Tsai et al. [15]), fund-raising strategies (Berrett and Slack [5]), (Slyke van and Brooks [57]); differentiation strategies (Barman [3]); strategic behaviours (Brown and Iverson [7]).

Non-profit organizations may reasonably compete against commercial organizations in certain markets, e.g. health care (Jarmon [31]). The use of competition analysis method and the marketing orientation improves the competitiveness of non-profit organizations (Pavičić, Renko and Alfirević [44]).

Charitable organizations employ positioning strategies which are a function of a wide variety of internal and external factors and performed at two levels: subsectoral and one which is part of the general response of the Third Sector to the environment where they compete for resources (Chew [13], Chew and Osborne [14]). Strategies should lead to an adequate positioning of the offer in specific market segment. Organizations that do not have a consistent strategy tend to have unsatisfactory performance (Mazzarol and Soutar [39]). 
Further, research studies examine the drive for innovation among non-profit organizations both as part of their strategies or as one of their core activities. Innovation in non-profits can be assessed using a threedimensional model and this may be part of an overall assessment of strategic management (Chien-Tzu Tsai et al. [15]).

Tim Berrett identifies key factors that affect non-profit organizations' ability to raise funds: use of media to promote projects and the level of participation (Berrett and Slack [5]).

One strategy typical of non-profit organizations is the fund-raising strategy designed to attract donations and financial support. Fund-raising strategies should be tailed to the social and demographic profile of potential donors (Slyke van and Brooks [57]).

Emily Barman analyses differentiation strategies. She claims that organizations use differentiation not only to improve competitiveness but also to mark their uniqueness and superiority over rivals (Barman [3]).

Organizations can be classified according to four strategic types: defenders, seekers, analysers and responders (Brown and Iverson [7]).

Finally, the last identified group of contemporary research papers address the applicability of tools and techniques in strategic management in the Third Sector. The tools and techniques include: the strategic score card (Schalm [56], Alfirević et al. [1], Speckbacher [59]), Inamdar et al. [30]); evaluation (Carman and Fredericks [11]), cognitive mapping (Johnson and Lipp [32]), computer-aided planning (Mara [38]), strategic groups analysis (Domański [20]). Largely, authors conclude that the specific tools and techniques can be used by non-profit organizations, possibly with some sector-specific modifications. They also describe specific outcomes resulting from the use of specific tools.

\section{Synthesis}

The identified papers can be summarised around four key areas of concern or dilemmas faced by modern management theory. First, how can the established commercial strategic management concepts and techniques be best adapted to the specific needs of the Third Sector? Secondly, and more generally, which of the existing schools of thought is the most relevant for the type of organization at hand? Is there a room for a brand new theory? Thirdly, how can management theory and research find a cohesive and consistent concept that explains the effective performance of a nonprofit organization. Lastly, how to address the strategic challenge of choosing between the willingness and need to employ competitive strategies and the relevance of opting for a collaborative strategy and a generally co-operative approach to the non-profit environment?

The sampled population of research studies suggest that in terms of non-profit management theory it is essential to note that established commercial concepts do to fit into the Third Sector setting, inter alia (Renshaw and Krishnaswamy [49], Moore [41]). Clearly, this statement originates from the perceived differences between strategic management in non-profit and forprofit organizations (Reeves and Ford [48]). The 'topdown' approach is especially criticised as inadequate for strategically managing non-profits (Paarlberg and Bielefeld [43]).

Hence, much of the conceptual work is focused on mission statement, goal setting, top level planning and communication to lower levels with a view to building tactics. Implementation is left to rank-andfile personnel. The above patter is inadequate for nonprofit organizations. Their operations must be guided by a wide group of stakeholders and this has a bearing on strategic management (Paarlberg and Bielefeld [43]). This is mentioned by Carney who stresses the need for a greater staff and middle-management involvement (Carney [12]).

There is ample evidence that the inclusion of stakeholders in strategic management is advantageous nonprofit organizations. It may boost the quality of management with more management dimensions properly addressed in strategic planning (Gunby Jr [27]). Moreover, it fosters effectiveness and improved performance (Balser and McClusky [2], Griggs [26], Bart and Tabone [4]). Surely enough, the involvement of clients in the process of, perhaps, not goal setting but identifying ways of goal implementation will help non-profit organizations build a more 'useful' offering. Such utility will be one of the keys to success (Crittenden [18]). The removal of pressure from key managers to deliver under strategic plans by delegating will help top management focus on day-to-day management in a volatile environment, claims Peter Frumkin (Frumkin and Casey [23]).

The review of research reveals that non-profit organizations recognise the need to include a broad spectrum 
of stakeholders in strategic planning. However, this concept is implemented by organizations with an extensive organizational structure with both voluntary and paid personnel, including administration (Crittenden and Crittenden [19]).

Hence, there seems to be a ready and universal answer to the challenge of applying commercial strategic management in non-profit organizations. The answer is 'Involve as many stakeholders as possible in this process and you will be successful'. But will you, really? Is such a democratic management at all feasible? Is democracy not the best of systems only because nobody has ever thought of a better one? And what about the cost of decision-making in such a model? In fact, cost is one of the major issues non-profit organizations must address (Speckbacher [58]). Consequently, there is a need for a 'golden means', a balance between the key role of top management and the marginal delegation of strategic planning responsibilities. What is the point of balance? Apparently, the answer to this question has not been found yet.

Another dilemma, a theoretical rather than a practical one, is: which school of management theory should strategic management of non-profit organizations be part of. Again, contemporary researchers are not single-minded about this and propose the resourceand competence-based view. An overwhelming majority of papers adhere to this school. Its adequacy for non-profit organizations is strongly argued by John Bryson who claims that a key competence-based livelihood scheme may be successfully applied by them (Bryson, Ackermann and Eden [10]). He goes on to argue that adequate management of key competences in the organization implies improved performance and is a strong basis for strategic planning. The concept of intellectual capital which belongs to this school of thought equally falls into the interests of modern research. Authors tend to recognise its effectiveness in the non-profit setting (Kong [35]).

Knowledge management is another concept which can and should be adapted to meet the needs of non-profit organizations (Renshaw and Krishnaswamy [49]) as is value management (Moore [41]). A wide spectrum of organizational resources are analysed and described: human resources (Taylor and McGraw [62], Ridder and McCandless [52]), including managers (Carney [12], Katsioloudes and Tymon [33], Vandijck, Desmidt and Buelens [63], Bart and Tabone [4], Frumkin and Casey [23], Hwang and Powell [29]); personnel
(Griggs [26]) and donors (LeRoux and Goerdel [37], Slyke van and Brooks [57]), and stakeholders (Paarlberg and Bielefeld [43], Speckbacher [58], Balser and McClusky [2], Crittenden and Crittenden [19], Bart and Tabone [4]), then non-tangible resources (Pike, Roos and Marr [47]), mainly reputation and image (Fillis [22]). The above demonstrates the absolute prevalence of the resource- and competence-based view in strategic management in the Third Sector.

The sole attempts to go beyond this view are limited to references to other established management theories for non-profit organizations such as systems theory (Starnes [60]) and the computational complexity theory (Paarlberg and Bielefeld [43]). They are viewed as useful tools. There are no theories around dedicated non-profit management concepts. Eva Reussner claims that a comprehensive strategic management model should not only rely on externalities, but mainly address the public function (Reussner [50]).

The special role in public value creation is also mentioned by Mark Moore (Moore [41]). At the level of strategy conceptualisation, one central non-profitspecific strategy is that of fund-raising (Berrett and Slack [5], Slyke van and Brooks [57]). Here, research papers call for a choice between membership and influence and between representation and control (Pijl and Sminia [46]) and a choice between tradition and innovation (Miller [40]). Most papers, however, focus on the established concepts or methods, perhaps addressing the unique applications in non-profit organizations. Researchers do not ask explicit questions that would lead them to new and unique concepts that consolidate the existing schools of thought in strategic management. This is a new challenge faced by the academic community. Theory should not only explore existing concepts but, perhaps first of all, search for new and better conceptual schemes.

The third dilemma is strategic management of nonprofit organizations is about their effectiveness and efficiency (including the effectiveness and efficiency of strategic planning), rationalisation and how specific strategic affect these parameters. Modern theory provides a wide variety of answers. Non-profits operate more effectively when they recognise and adequately respond to their environment which quite often offers a high level of motivation (Hafsi and Thomas [28], Griggs [26]). A well defined mission will be an effective response (Vandijck, Desmidt and Buelens [63]), and the formulation process should involve 
the following steps: introduction, and the analysis of: inputs, communication, connotations and applicability (Cochran, David and Gibson [16]). Mission statement is one of the strategic dimensions used by nonprofit organization (Rhodes and Keogan [51]), and the lack of a mission statement implies inadequate performance (Mazzarol and Soutar [39]). Non-profit organizations become successful if the various strategies they employ are closely interrelated, based on fund-raising from diverse sources, use marketing tools and grow by strengthening the utility of their offer (Crittenden [18]). Strategies in philanthropic organizations are more effective and support growth and viability when they are not hinged upon autonomy as a core value. Note that the selection of a strategy should be driven by its effectiveness and efficiency (Golensky and Mulder [24]). The selection of a strategy is part of strategic planning which can be effectively supported with IT tools (Mara [38]) and which helps organizations concentrate on changes in the environment (Bratt [6]). Furthermore, strategic planning is positively correlated with performance in the following dimensions: external environmental orientation, functional orientation and focus on key personnel involvement (Griggs [26]). The key personnel are managers and non-profit organizations (Hwang and Powell [29]). Managers should have lobbying skills (LeRoux and Goerdel [37]). While they seem to recognise the insufficient contribution of analytics into the strategic management process (Katsioloudes and Tymon [33]), they have the biggest impact on the organization's mission (Bart and Tabone [4]). As noted earlier, the process should involve other stakeholders as there is a positive correlation between the involvement of a wide spectrum of stakeholders in creating the mission and the performance of the organization. The process should not be top-down but a fairly informal and creative coparticipation of as many stakeholders as possible (Bart and Tabone [4]). Stakeholder involvement will facilitate strategy implementation (Carney [12]). Finally, organizations which build their external relations by consistently creating among their stakeholders a perception of a well managed structure tend to receive higher ratings on effectiveness (Balser and McClusky [2]) in external evaluations, as described by Joanne Carman (Carman and Fredericks [11]). One of the core and at the same time unique strategies of a non-profit organization is its fund-raising strategy. This strategy should be aligned with the social and demographic characteristics of prospective donors
(Slyke van and Brooks [57]). Among key success factors of a non-profit fund-raising strategy is the appropriate use of the media (to promote projects) and the level of participation (Berrett and Slack [5]). Researchers point to a performance measurement tool which is likely to be most suitable for non-profits, i.e. the Strategic Score Card (Schalm [56], Alfirević et al. [1], Speckbacher [59], Inamdar et al. [30]).

A question arises as to whether we are, in fact, missing a single coherent theory that would explain and measure performance in the Third Sector. Where profit is not a goal what is? What is the single most important goal that non-profit organizations are trying to meet? Is it to increase the stakeholder value (as opposed to shareholder value in commercial organizations)? How can you measure the value in the absence of a market valuation mechanism such as the share price? These questions are still to be answered.

Another challenge to contemporary research on strategic management in the Third Sector is about the type of strategy that should be pursued, and more specifically, whether the guiding principle should be competition or co-operation with other players in the sector. This dilemma appears to be solved already at the first glance as the majority of writers on the subject underline the need intrasectoral competition. Kent Miller suggests that non-profit organizations should be seen as competitive, which implies a number of observations regarding their strategies (Miller [40]). In this context, competition is mainly for resources in the environment and it is becoming a major factor affecting performance (LeRoux and Goerdel [37]).

Competition and marketing orientation analysis is postulated as key method of improving competitiveness (Pavičić, Renko and Alfirević [44]). Further, the strategic group analysis can be successfully applied in this sector as it will help identify the closest competitors and barriers to entry to other, less competition-intensive areas of operation (Domański [20]). The competitive dimension, however, goes beyond rivalry between other organizations in the non-profit sector. Indeed, non-profits can aggressively compete against commercial organizations in certain markets, e.g. health care (Jarmon [31]).

Non-profit organizations employ positioning strategies which are a function of both external and internal factors and are executed at two levels; sub-sectoral and sectoral, the latter being part of the Third Sector's general response to the pressures of the environment where 
they compete for resources (Chew [13], Chew and Osborne [14]). Another strategy is that of differentiation where the goal is to promote uniqueness and superiority over rivals (Barman [3]). Four strategic behaviours are identified: defenders, seekers, analysers and responders (Brown and Iverson [7]). In contrast, Becky Starnes pushes competition to the sidelines and argues in favour of strategic alliances. She claims non-profit organizations should be managed as open systems and form strategic alliances to pursue their missions (Starnes [60]). Also, Kent Miller, points out that religious organizations that he has researched could employ collaborative strategies (Miller [40]). Mark Moore concludes that the strategic model based partly on competition that has been used by commercial organizations is not adequate for non-profit organizations (Moore [41]).

In the context of these observations and the fact that a large majority of non-profit organizations not only fail to protect their key skills against competition but indeed in the name of public good share their good practices with others in the same market one may ask a fundamental question whether the theory of Third Sector management should not place a far greater emphasis on the concepts of collaborative, alliance-based and co-operative strategies. Such an approach would be much closer to reality and could yield a more faithful description of the status quo of non-profit organizations. Moreover, it can produce more efficient management strategies and methods. This is the role of applied research studies such as the study of management.

\section{Conclusion}

This paper aimed at reviewing contemporary literature on strategic management in non-profit organizations. Whereas much could have changed in management theory since Melissa Stone outlined her findings from a study of management literature between 1977 and 1992 it seems pertinent that a similar review should be conducted to identify focus areas and proposed concepts in the early year of the $21^{\text {st }}$ century. Our study has concluded that from 2000 through to mid-2009 (9,5 years) there were some 50 publications, of which 21 were mainly surveys, 5 were case studies, 5 monographies, 17 used the intuitive method and 2 were critical reviews of existing literature.
While analysing the areas of interest of contemporary authors it is clear that there are five such fields: modern management and strategic management approaches /theories; analysis of the roles of externalities and internalities in the Third Sector; review of how strategic management has been applied for non-profit organizations; review of applications and enhanced identification of one or more strategies utilised by non-profit organizations; application of specific methods and tools in strategic management.

Four dilemmas faced by modern management theory serve as a synthetic axis. First, how can the existing commercial management concepts and techniques be best adapted to the realities of the non-profit sector? Secondly, which of the established schools of strategic management is the most relevant one for non-profits? In fact, is it appropriate to look for a brand new school of thought? Thirdly, and this is again related to academic pursuits, what coherent theory can explain the efficiency of non-profit organizations. Fourthly, there is the dilemma what strategy to employ when faced with a choice between the willingness and the need to apply competitive strategies and the cooperative strategy in the third sector.

\section{References}

[1] Alfirević N., Pavičić J., Adžić B., Šimurina J., Bratić V. - The Balanced Scorecard (Bsc) Approach to Performance of a Nonprofit in the Transition Environment: the Case of the Commercial Trade Union of Croatia (Ctu) [at] Conference Proceedings: International Conference Enterprise in Transition, 2005, pp. 5-19.

[2] Balser D., McClusky J. - Managing stakeholder relationships and nonprofit organization effectiveness [in] Nonprofit Management \& Leadership 15 (3), 2005, pp. 295-315.

[3] Barman E.A. - Asserting Difference: The Strategic Response of Nonprofit Organizations to Competition [in] Social Forces 80 (4), 2002, pp. 1191-1223.

[4] Bart C.K., Tabone J.C. - Mission statements in Canadian not-for-profit hospitals: Does process matter? [in] Health care management review 25 (2), 2000, pp. 45-63.

[5] Berrett T., Slack T. - A Framework for the Analysis of Strategic Approaches Employed by Non-profit Sport Organizations in Seeking Corporate Sponsorship [in] Sport Management Review 4 (1), 2001, pp. 21-45. 
[6] Bratt R.G. - Challenges for Nonprofit Housing Organizations Created by the Private Housing Market [in] Journal of Urban Affairs 31 (1), 2009, pp. 67-96.

[7] Brown W.A., Iverson J.O. - Exploring Strategy and Board Structure in Nonprofit Organizations [in] Nonprofit \& Voluntary Sector Quarterly 33 (3), 2004, pp. 377-400.

[8] Bryson J.M. - Strategic Planning for Public and Nonprofit Organizations. Jossey-Bass, San Francisco 1995.

[9] Bryson J.M. - A Strategic Planning Process for Public and Non - profit Organizations [in] Long range planning 21 (1), 1988, pp. 73-81.

[10] Bryson J.M., Ackermann F., Eden C. - Putting the Resource-Based View of Strategy and Distinctive Competencies to Work in Public Organizations [in] Public administration review 67 (4), 2007, pp. 702-717.

[11] Carman J.G., Fredericks K.A. - Nonprofits and Evaluation: Empirical Evidence from the Field [in] New Directions for Evaluation (119), 2008, pp. 51-71.

[12] Carney M. - Middle manager involvement in strategy development in not-for profit organizations: the director of nursing perspective - how organizational structure impacts on the role [in] Journal of nursing management 12 (1), 2004, pp. 13-21.

[13] Chew C. - Positioning and its strategic relevance [in] Public Management Review 8 (2), 2006, pp. 333-350.

[14] Chew C., Osborne S.P. - Identifying the Factors That Influence Positioning Strategy in U.K. Charitable Organizations That Provide Public Services: Toward an Integrating Model [in] Nonprofit \& Voluntary Sector Quarterly 38 (1), 2009, pp. 29-50.

[15] Chien-Tzu Tsai, Pao-Long Chang, Tzu-Chuan Chou, Yih-Ping Cheng. - An integration framework of innovation assessment for the knowledgeintensive service industry [in] International Journal of Technology Management 30 (1), 2005, pp. 85104.

[16] Cochran D.S., David F.R., Gibson C.K. A Framework for Developing an Effective Mission Statement [in] Journal of Business Strategies 25 (2), 2008, pp. 27-39.

[17] Courtney R. - Strategic Management for Voluntary Nonprofit Organizations. Routledge: London and New York 2002.
[18] Crittenden W.F. - Spinning Straw into Gold: the Tenuous Strategy, Funding, and Financial Performance Linkage [in] Nonprofit \& Voluntary Sector Quarterly 29, 2000, pp. 164-182.

[19] Crittenden W.F, Crittenden V.L. - Relationships Between Organizational Characteristics and Strategic Planning Processes in Nonprofit Organizations [in] Journal of Managerial Issues 12 (2), 2000, pp. 150-169.

[20] Domański J. - Strategic Group Analysis of Poland's Non-Profit Organizations. Nonprofit and Voluntary Sector Quarterly doi:10.1177/0899764009338219, 2009.

[21] Drucker P.F. - Zarzadzanie organizacja pozarzqdowa - teoria i praktyka. Wyd. Fundusz Współpracy - Program PHARE, Dialog społeczny NGO's, Warszawa 1995.

[22] Fillis I. - Image, Reputation and Identity Issues in the Arts and Crafts Organization [in] Corporate Reputation Review 6 (3), 2003, pp. 239-251.

[23] Frumkin P., Casey A.E. - Creating New Schools: The Strategic Management of Charter Schools. Report. Annie E. Casey Foundation 2003.

[24] Golensky M., Mulder C.A. - Coping in a Constrained Economy: Survival Strategies of Nonprofit Human Service Organizations [in] Administration in Social Work 30 (3), 2006, pp. 524.

[25] Goold M. - Institutional advantage: A way into strategic management in not-for-profit organizations [in] Long Range Planning 30 (2), 1997, pp. 291-293.

[26] Griggs H.E. - Corporatisation of the Not-ForProfit Sector: strategic planning and organizational performance in disability-based organizations [in] International Journal of Disability, Development \& Education 50 (2), 2003, pp. 197-220.

[27] Gunby Jr N.W. - Firm performance and complementary strategy development processes [in] Management Decision 47 (5), 2009, pp. 7-7.

[28] Hafsi T., Thomas H. - Strategic Management and Change in High Dependency Environments: The Case of a Philanthropic Organization [in] Voluntas: International Journal of Voluntary \& Nonprofit Organizations 16 (4), 2005, pp. 329-351.

[29] Hwang H, Powell W.W. - The Rationalization of Charity: The Influences of Professionalism in the Nonprofit Sector [in] Administrative Science Quarterly 54 (2), 2009, pp. 268-298. 
[30] Inamdar S.N., Kaplan R.S., Jones M.L., Menitoff R. - The Balanced Scorecard: a strategic management system for multi-sector collaboration and strategy implementation [in] Quality management in health care 8 (4), 2000, pp. 21-39.

[31] Jarmon R. - Quality Levels of For-Profit and Nonprofit Competitors: a Review of Studies in Health Care [at] Allied Academies International Conference: Proceedings of the Academy of Strategic Management (ASM) 7 (1), 2008, pp. 35-40.

[32] Johnson R., Lipp A. - Cognitive Mapping: A Process to Support Strategic Planning in an Academic Department [in] Group Decision \& Negotiation 16 (1), 2007, pp. 43-60.

[33] Katsioloudes M.I., Tymon W.G. - Strategic Planning Practices: Are they what they should be? [in] Human Systems Management 22 (4), 2003, pp. 177-183.

[34] Kemp R.L, Kemp J.D. - A New Planning Model for the Public and Nonprofit Sector [in] Management Research News 15 (2), 1992, pp. 1-3.

[35] Kong E. - The strategic importance of intellectual capital in the non-profit sector [in] Journal of Intellectual Capital 8 (4), 2007, pp. 721-731.

[36] Lauer L.D. - Nonprofits Going Global Opportunities and Problems from a Communicator's Perspective [in] Nonprofit World 13 (6), 1995, pp. 4548.

[37] LeRoux K., Goerdel H.T. - Political Advocacy by Nonprofit Organizations: A Strategic Management Explanation [in] Public Performance \& Management Review 32 (4), 2009, pp. 514-536.

[38] Mara C.M. - A Strategic Planning Process for a Small Nonprofit Organization [in] Nonprofit Management \& Leadership 11 (2), 2000, pp. 211223.

[39] Mazzarol T.W., Soutar G.N. - Strategy matters: strategic positioning and performance in the education services sector [in] International Journal of Nonprofit \& Voluntary Sector Marketing 13 (2), 2008, pp. 141-151.

[40] Miller K.D. - Competitive Strategies of Religious Organizations [in] Strategic Management Journal 23 (5), 2002, pp. 435-456.

[41] Moore M.H. - Managing for Value: Organizational Strategy in for-Profit, Nonprofit, and Governmental Organizations [in] Nonprofit \& Voluntary Sector Quarterly 29, 2000, pp. 183-208.
[42] Mulhare E.M. - Mindful of the future: Strategic planning ideology and the culture of nonprofit management [in] Human organization 58 (3), 1999, pp. 323-331.

[43] Paarlberg L.E., Bielefeld W. - Complexity Science An Alternative Framework for Understanding Strategic Management in Public Serving Organizations [in] International Public Management Journal 12 (2), 2009, pp. 236-260.

[44] Pavičić J., Renko N., Alfirević N. - The Role of Competitive Analysis and Marketing Orientation in Improving Competitiveness of the Non-profit Sector - Theoretical Background and Empirical Evidence [at] Conference Proceedings: 2001 International Conference Enterprise in Transition, 2001, pp. 422-437.

[45] Pieter J. - Ogólna metodologia pracy naukowej. Ossolineum, Wrocław 1967.

[46] Pijl Kvd, Sminia H. - Strategic Management of Public Interest Organizations [in] Voluntas: International Journal of Voluntary \& Nonprofit Organizations 15 (2), 2004, pp. 137-155.

[47] Pike S., Roos G., Marr B. - Strategic management of intangible assets and value drivers in $R \& D$ organizations [in] R\&D Management 35 (2), 2005, pp. 111-124.

[48] Reeves T.C., Ford E.W. - Strategic management and performance differences: nonprofit versus forprofit health organizations [in] Health care management review 29 (4), 2004, pp. 298-308.

[49] Renshaw S., Krishnaswamy G. - Critiquing the Knowledge Management Strategies of Non-profit Organizations in Australia [in] Proceedings of World Academy of Science: Engineering \& Technology 37, 2009, pp. 456-464.

[50] Reussner E.M. - Strategic management for visitororiented museums [in] International Journal of Cultural Policy 9 (1), 2003, pp. 95-108.

[51] Rhodes M.L, Keogan J.F. Strategic Choice in the Non-Profit Sector: Modelling the Dimensions of Strategy [in] Irish Journal of Management 26 (1), 2005, pp. 122-135.

[52] Ridder H., McCandless A. - Influences on the Architecture of Human Resource Management in Nonprofit Organizations: An Analytical Framework. Nonprofit and Voluntary Sector Quarterly doi: 10.1177/0899764008328182, 2008.

[53] Salamon L.M., Anheier R.K. - The Emerging Nonprofit Sector: An Overview. University Press, Manchester 1996. 
[54] Salamon L.M., Anheier H.Ka.A. - The Emerging Sector Revisited [in] A Summary Revised Estimates, CNP The Johns Hopkins Comparative Nonprofit Sector Project, Phase II, 1999, pp. 1-32.

[55] Sargeant A. - Marketing $w$ organizacjach non profit. Oficyna Ekonomiczna, Kraków 2004.

[56] Schalm C. - Implementing a balanced scorecard as a strategic management tool in a long-term care organization [in] Journal of health services research \& policy 13 (1), 2008, pp. 8-14.

[57] Slyke van D.M., Brooks A.C. - Why do People Give? New Evidence and Strategies for Nonprofit Managers [in] American Review of Public Administration 35 (3), 2005, pp. 199-222.

[58] Speckbacher G. - Nonprofit versus corporate governance: An economic approach [in] Nonprofit Management \& Leadership 18 (3), 2008, pp. 295320.

[59] Speckbacher G. - The Economics of Performance Management in Nonprofit Organizations [in] Nonprofit Management \& Leadership 13 (3), 2003, pp. 267-282.
[60] Starnes B.J. - Achieving Competitive Advantage Through the Application of Open Systems Theory and the Development of Strategic Alliances: A Guide for Managers of Nonprofit Organizations [in] Journal of Nonprofit \& Public Sector Marketing 8 (2), 2000, pp. 15-28.

[61] Stone M.M., Bigelow B., Crittenden W. - Research on Strategic Management in Nonprofit Organizations [in] Administration \& Society 31 (3), 1999, pp. 378-423.

[62] Taylor T., McGraw P. - Exploring Human Resource Management Practices in Nonprofit Sport Organizations [in] Sport Management Review 9 (3), 2006, pp. 229-251.

[63] Vandijck D., Desmidt S., Buelens M. - Relevance of mission statements in Flemish not-for-profit healthcare organizations [in] Journal of nursing management 15 (2), 2007, pp. 131-141. 